\title{
NO PRINCÍPIO ERA O VERBO: A CULTURA ESCOLAR E O ENSINO DA LÍNGUA VERNÁCULA NO ENSINO SECUNDÁRIO BRASILEIRO (1759-1960) ${ }^{1}$
}

IN THE BEGINNING WAS THE WORD: SCHOOL CULTURE AND VERNACULAR LANGUAGE TEACHING IN BRAZILIAN SECONDARY EDUCATION (1759-1960)

Luci Schmoeller | Lattes | lucischmoeller@hotmail.com Universidade Federal de Santa Catarina

\author{
Norberto Dallabrida | Lattes | norberto.dallabrida@udesc.br \\ Universidade do Estado de Santa Catarina
}

\begin{abstract}
Resumo: O objetivo deste artigo é explicar as prescrições que forjaram a Cultura Escolar em torno do ensino da língua vernácula no ensino secundário brasileiro, através da análise histórica do processo de constituição da disciplina Português, que se inicia com a imposição do português como língua materna - 1759 - até o início do processo de democratização do ensino que vai modificá-la expressivamente - 1960. Veremos que o nascimento da disciplina está atrelado à constituição da nação brasileira e ao sentimento nacionalista, o que vai reverberar no modo de ver e pensar o ensino da língua vernácula até os dias de hoje.
\end{abstract}

Palavras-chave: Cultura Escolar; Língua Portuguesa; Ensino Secundário.

\begin{abstract}
The purpose of this article is to explain the requirements that forged the School Culture around the vernacular language teaching in the Brazilian secondary education through historical analysis of the process of constitution of the Portuguese course, which begins with the imposition of the Portuguese language as the national mother tongue - 1759 - until the beginning of the school democratization process that will modify it significantly - 1960. We will see that the birth of the subject is linked to the formation of the Brazilian nation and the nationalist sentiment, which will reverberate in the way of seeing and thinking vernacular language teaching until today.
\end{abstract}

Key-words: School culture; Portuguese language; Secondary education.

\footnotetext{
${ }^{1}$ Trabalho desenvolvido na Disciplina "Cultura Escolar e Instituições”, ministrada pela Professora Gladys Teive, no Programa de Pós-graduação em Educação da Universidade do Estado de Santa Catarina (UDESC), no primeiro semestre de 2015. Este trabalho será parte integrante de tese em desenvolvimento, a ser defendida em dezembro de 2017.
} 


\section{Introdução}

Nos últimos anos, os olhares se voltaram ao ensino médio principalmente pelos resultados nada satisfatórios nas avaliações nacionais e internacionais. Sabe-se que essa conjuntura é resultado de raízes históricas: os professores do ensino médio não recebem uma boa formação inicial e a formação continuada é também deficiente, além de terem salários nada atrativos; de outra parte, os alunos que frequentam a escola pública geralmente trazem como repertório uma língua e uma cultura socialmente desvalorizadas. A escola não é eficiente em imbuí-los da cultura necessária para inseri-los na sociedade letrada. Trocando em miúdos, a escola não promove a democratização das oportunidades de ascensão social e política da grande massa trabalhadora.

O interessante é pensar nas mais diferentes teorias que surgiram para tentar resolver o problema da educação nas escolas públicas e em quão inócuas elas foram. Segundo Azanha (1990, p. 69) "é no interior da sala de aula que se decide o destino de políticas e reformas educacionais." Nos últimos vinte anos, a escola deixou de ser vista como um lugar em que nada separa as intenções dos resultados. As problemáticas da história da educação refinaram-se para a diferença - ou hiato, conforme Carvalho (2003) - entre o que se prescreve nas propostas curriculares e o que realmente se faz na escola, até então as contribuições da história se mostravam demasiado externalistas. É nesse sentido que, segundo Chervel (1990), a história das disciplinas escolares tenta identificar, através das práticas de ensino, o que ocorre nesse espaço particular, e leva a pôr em evidência o caráter efetivamente criativo do sistema escolar.

O objetivo deste texto é evidenciar as prescrições - sem se ater aos usos que os sujeitos fizeram dessas prescrições -, e as transformações pelas quais passaram, que forjaram a cultura escolar em torno do ensino da língua vernácula no Brasil no ensino secundário. Isso se dará por meio da análise histórica que se inicia com a imposição do português como língua materna - 1759 - até o início do processo de democratização do ensino que vai modificar expressivamente a disciplina - 1960. Veremos que o processo de constituição da disciplina de português está atrelado ao da constituição da nação brasileira e ao sentimento nacionalista decorrente desse processo, o que vai reverberar no modo de ver e pensar a disciplina de Português até os dias de hoje.

\section{Cultura escolar: história das disciplinas escolares}

A História da Educação vem redesenhando seus métodos e objetos de investigação, reformulando suas interrogações e se abrindo para novos interesses e novos critérios de tratamento do arquivo, re-historicizando a escola. A instituição escolar passa a ser conce- 
bida como produto histórico, que tem práticas sociais próprias. Assim nasceu a noção de Cultura Escolar.

O conceito de cultura escolar proposto por Viñao Frago (1995, p. 68-69) parte da compreensão de cultura escolar como um "conjunto de aspectos institucionalizados que caracterizam a escola como organização”. É a cultura específica de um estabelecimento ou um "aspecto individualizado de determinado grupo, de professores [...]" (GONÇALVES, 2006, p. 21), aspectos que irão atribuir características e modos de ser e ver que são particulares, tanto em relação às materialidades quanto aos significados simbólicos do mundo da escola. Tais aspectos, segundo Viñao Frago (1995, p. 68-69), inclui:

Práticas y conductas, modos de vida, hábitos y ritos - a historia cotidiana del hacer escolar -, objetos materiales - función, uso, distribución en el espacio, materialidad física, simbologia, introducción, transformación, desaparición... -, y modos de pensar, así como significados e ideas compartidas.

Portanto, se a cultura escolar envolve toda a vida escolar, a construção das ideias sobre o ensinar e o aprender até a ação efetiva desse fazer escolar fazem parte desta cultura.

Para Dominique Julia (2001, p. 10), cultura escolar é entendida "como um conjunto de normas que definem conhecimentos a ensinar e condutas a inculcar, e um conjunto de práticas que permitem a transmissão desses conhecimentos e a incorporação desses comportamentos”. Nesse sentido, o conceito de cultura escolar desvia o olhar para o interior da escola e deixa de lado os objetos de investigação que se debruçam sobre a história das instituições ou história das ideias, consideradas por Julia como "demasiado externalistas" (JULIA, 2001, p. 12). É o que, segundo ele, tem feito a história das disciplinas escolares quando se propõe a "compreender o que ocorre nesse espaço particular" (JULIA, 2001, p. 13).

Esse novo campo de pesquisa "articula-se ao processo de transformações curriculares dos anos de 1970 e decorrer da década de 1980", pois a ideia da escola como espaço de reprodução de conhecimentos ${ }^{2}$ imposto era repensada (BITTENCOURT, 2003, p. 11). Da visão da escola e seus agentes, como uma teia de articulações mais complexa, emergia uma nova produção historiográfica. A organização dos saberes escolares passou a ser incluída como um dos objetos importantes sobre as práticas escolares, não só no Brasil, mas em diferentes países, quase que simultaneamente. Conforme Bittencourt (2003, p. 15),

\footnotetext{
${ }^{2}$ Bittencourt (2003) refere-se aos estudos de Bourdieu e Passeron e de Ivan Illich.
} 
Na França, Inglaterra, Portugal, México, Canadá, entre outros países, incluindo o Brasil, houve um crescimento de pesquisas sobre a disciplina escolar que, entre outros problemas, possuíam em comum a preocupação em identificar a gênese e os diferentes momentos históricos em que se constituem os saberes escolares, visando perceber a sua dinâmica, as continuidades e descontinuidades no processo de escolarização.

A história das disciplinas escolares, como afirmou Julia, "abre a caixa preta da escola” (2001, p. 13), quando as concebe como produtos específicos da escola que põem em evidência o sistema escolar. Julia, pautado nos estudos de Andre Chervel, aponta que as pesquisas sobre a história das disciplinas escolares explicitam uma ampla liberdade de manobra entre o prescrito e o praticado (JULIA, 2001). Em outras palavras, há uma distância entre o que é normatizado e o que é verdadeiramente praticado na escola.

Segundo Chervel, a escola não é um simples espaço de transmissão de saberes, ela é um espaço de produção de sua própria cultura (1990). A partir disso, ele atribui um papel importante à história das disciplinas escolares:

\begin{abstract}
Se se pode atribuir um papel "estruturante à função educativa da escola na história do ensino", é devido a uma propriedade das disciplinas escolares. $\mathrm{O}$ estudo dessas leva a pôr em evidência o caráter eminentemente criativo do sistema escolar e, portanto, classificar no estatuto dos acessórios a imagem de uma escola encerrada na passividade, de uma escola receptáculo dos subprodutos culturais de uma sociedade. (CHERVEL, 1990, p. 184).
\end{abstract}

Inventariar as maneiras diferenciadas de ensino é conhecer as práticas dos atores que participaram da produção daquela cultura escolar. É nessa perspectiva que hoje está presente em muitas pautas de investigação esse objeto histórico de investigação: a atenção se volta para o cotidiano da escola, desloca-se do seu eixo externo, ou seja, dos modelos pedagógicos regulamentares, preceituais e normativos para as práticas diferenciadas de apropriação desses modelos em cada disciplina-saber.

No senso comum, a escola ensina as ciências impostas pela cultura na qual a sociedade se banha; não passa de um puro e simples agente de transmissão de saberes elaborados fora dela; a escola seria, portanto, um lugar do conservadorismo, da inércia e da rotina. No entanto, para Chervel (1990, p. 185), "a história das disciplinas escolares pode desempenhar um papel importante não somente na história da educação, mas na história cultural”, ao perceber que, de fato, o sistema escolar forma os indivíduos e uma cultura escolar que vem, por sua vez, penetrar, moldar e modificar a cultura da sociedade global. Esse papel ativo e criativo que a escola desempenha só é possível evidenciar a partir da pesquisa da história das disciplinas escolares. 


\section{Genealogia do ensino da língua vernácula: deitando raízes na cultura escolar}

No presente, é inconcebível imaginar uma escola no Brasil sem a disciplina de português, isso já se naturalizou entre nós; no entanto, os estudos históricos mostram que o ensino da língua vernácula teve uma entrada tardia na escola brasileira - somente no século XIX - e dependeu de diversos fatores para se consolidar nas práticas escolares, principalmente no ensino secundário. Houve dois momentos importantes para a constituição da disciplina: a reforma implementada por Pombal, que instituiu o português como língua oficial e a reforma de 1931, assinada pelo ministro Francisco Campos, em que o ensino da língua vernácula se tornou obrigatório em todos os anos do ensino fundamental. (ALMEIDA, 1997; BRASIL, 1931). Então, para entender como se deu o processo de constituição dessa disciplina no ensino secundário brasileiro, é preciso fazer uma genealogia do ensino da língua vernácula no Brasil.

Segundo Souza (2008), quando éramos colônia de Portugal, o ensino secundário era insipiente e oferecido principalmente pelos seminários e colégios jesuítas que eram adeptos da formação humanista - herança deixada pelos colégios europeus que visavam à formação do espírito, preparando os jovens para ascenderem aos mais altos níveis do pensamento utilizando a retórica, a arte de pensar e de escrever. Todo o ensino secundário e superior dos jesuítas era fundamentado no latim - era o que determinava a Ratio Studiorum. (ROOTHAAN, 1850). O português era somente um instrumento de alfabetização, como apoio para aprender a gramática latina, e língua falada. Coube ao Marquês de Pombal reformar os estudos em Portugal e suas colônias, foi quando se tornou obrigatório o uso da língua portuguesa como língua oficial - em 1759; as medidas impostas por ele contribuíram significativamente para a consolidação da língua vernácula no Brasil e sua inclusão como saber escolar (SOARES, 2004). Ainda conforme Soares (2004), com a reforma instituída por Pombal e sua política antijesuítica, essas instituições foram suprimidas e, apesar do fechamento das escolas da Companhia de Jesus, pouco foi feito para substituí-las e para criar um sistema de ensino secundário no Brasil. Esse ato radical de Pombal desmantelou o sistema colonial de ensino jesuítico, mas, segundo Piletti (1987), a tradição de ensino jesuítico, que tinha como conteúdos predominantes o ensino pautado nas humanidades, manteve-se nas poucas aulas régias, uma vez que os professores dessas aulas haviam sido formados na tradição pedagógica jesuítica.

Essas aulas-régias de latim, grego, retórica e filosofia passaram a funcionar como aulas avulsas. Segundo Piletti (1987), cada uma constituía uma unidade de ensino, com um professor único, era autônoma e isolada, não se articulava com outras aulas e nem 
pertencia a nenhuma escola, não havia currículo e nem uma duração prefixada. A partir da década de 1830, começaram a aparecer os primeiros liceus provinciais, que se constituíram mais pelo ajuntamento das aulas-régias do que como um sistema de ensino. Esses liceus preocupavam-se em oferecer aos alunos disciplinas exigidas para o ingresso aos cursos superiores (PILETTI, 1987) - somente a partir de 1871 é que foi implementado o exame de português.

Em 1837, o governo regencial criou o Colégio Pedro II, cujos primeiros planos de estudos incluíam e enfatizavam a cultura clássica humanista, seguindo a tradição dos sistemas pedagógicos da época. A disciplina Língua Portuguesa surge nesse momento, quando foi incluída no currículo do Colégio Pedro II, sob o nome de Retórica e Poética. Conforme Soares (2004), no ano seguinte, a gramática nacional é mencionada no regulamento do colégio. Porém, o marco inicial do ensino oficial de português como disciplina é considerado a partir do decreto imperial de 1871, quando é criado o cargo de "professor de português" (SOARES, 2004, p. 165). Nessa época, ainda não existiam instâncias de formação do professor de português, que era quase sempre um estudioso da língua e de sua literatura. As faculdades de filosofia, que tinham esse objetivo, surgem apenas nos anos 1930 (SOARES, 2004).

Os poucos cursos superiores existentes no país exigiam "certidões de aprovação" que eram conferidas por professores autorizados pelo governo que ministravam as aulas avulsas de uma ou mais disciplinas (RAZZINI, 2000, p. 25) - o que estaria na origem da educação essencialmente propedêutica que caracterizou fortemente o ensino secundário no Brasil. Segundo Razzini (2000, p. 36), até 1931, a conclusão do curso secundário não era obrigatória para entrar nos cursos superiores, cuja seleção era feita pelos "Exames Preparatórios”. Esses passaram a ser realizados em conformidade com os programas do Imperial Colégio Pedro II, que deveriam ser adotados também pelos colégios provinciais ou particulares (VECHIA; LORENZ, 1998). Isto fez com que, na prática, o currículo do curso secundário ficasse dependente desses exames, inclusive o currículo da Língua Portuguesa.

A importância dada ao ensino das humanidades estava em queda, apesar de cultivada em algumas instâncias do ensino secundário. Conforme Souza (2008), em 1854, o ministro Couto Ferraz, inspirado em novos modelos europeus, instituiu uma diversificação dos estudos secundários no Colégio Pedro II: a) os estudos técnicos tinham uma formação científica e prática e eram destinados aos alunos que não desejassem prosseguir até o bacharelado; b) os estudos de caráter essencialmente literários destinavam-se à for- 
mação de bacharéis em letras. Esses bacharéis, que cultivavam grande distinção social, costumavam exercitar a arte da escrita e liam, reproduziam e declamavam poesias nas salas de aula e em eventos sociais (SOUZA, 2008). Considerado o colégio modelo para o país até 1931, os alunos do Pedro II independiam dos exames preparatórios, pois o diploma de "Bacharel em letras" lhes dava o direito de ingressar em qualquer faculdade do império (RAZZINI, 2000, p. 25).

A constituição da disciplina Português, que teve início no Colégio Pedro II, foi determinada pela natureza dos conhecimentos que se tinha sobre a língua e pela formação dos profissionais que atuavam na área (SOARES, 2004). O aparecimento e a disseminação de uma nova perspectiva face aos estudos da linguagem, enveredando pela linguística, deram novo rumo às práticas pedagógicas das línguas modernas, assim como das línguas mortas (RAZZINI, 2000). Os estudos linguísticos acerca do português foram se constituindo paulatinamente e, com a instalação da Impressão Régia do Rio de Janeiro, a partir de 1808, houve condições de publicação para várias obras sobre a gramática do português. Soares (2004) chama a atenção para o fato de que essas gramáticas eram escritas por professores e destinadas a outros professores e alunos, o que atesta a tradição do ensino das normas gramaticais no currículo escolar até os dias de hoje. A língua portuguesa se constituiu como um sistema linguístico a partir desses trabalhos e, embora haja inúmeras variações linguísticas, o ensino da gramática foi concebido como modalidade única, travando uma luta acirrada contra as variações até de pronúncia.

Quanto a isso, Carlos Alberto Faraco (2004) problematiza a origem da norma padrão brasileira e, consequentemente, a institucionalização dessa norma como saber escolar. Ele observa que "a elite letrada conservadora se empenhou em fixar como nosso padrão um certo modelo lusitano de escrita” (FARACO, 2004, p. 42), diferentemente do que se pensa que o modelo foi tomado da língua de Portugal. Por trás dessa atitude está o desejo de viver num país branco e europeu de tradição latina. Houve, portanto, uma reação a um abrasileiramento da norma padrão, combatendo fenômenos linguísticos de caráter multirracial, sinônimo de corrupção e degeneração, fixando uma norma padrão artificialmente forjada que vê como erros fenômenos amplamente correntes até mesmo na norma culta. Segundo Faraco (2004), esse foi um fator pesado de discriminação e exclusão social e que influenciou sobremaneira o processo histórico da constituição do ensino da língua vernácula no país e que forjou as características que perduram até os dias de hoje. É importante ressaltar que o Colégio Pedro II teve um papel decisivo na orientação do ensino secundário brasileiro e na formação da disciplina de Português - 
até 1931 serviu de padrão nacional. Alguns dos livros didáticos de gramática e retórica foram escritos pelos professores do colégio, sendo que alguns deles foram utilizados até as primeiras décadas do século XX, como afirma Soares (2004). Algumas publicações tiveram destaque como a Gramática Portuguesa de Júlio Ribeiro; as Gramáticas expositivas de Eduardo Carlos Pereira, entre outras (SOARES, 2004). Além das gramáticas, destacaram-se também as coletâneas de textos utilizadas nas aulas, que apresentavam trechos de autores consagrados. Mais tarde, o poder desses professores se tornou hegemônico, pois, cada um na sua cátedra, decidia o programa curricular e os compêndios utilizados no curso, além dos conteúdos exigidos nos exames preparatórios.

A coletânea dos conteúdos programáticos ensinados na escola secundária (18501951), organizada por Vechia e Lorenz (1998), traz no introito o programa de exames para ingresso nos cursos superiores, publicado no ano de 1850. Nele, a gramática nacional aparece como conteúdo curricular apenas no primeiro ano e contempla apenas aspectos da morfologia da língua, dando ênfase ao ensino dos verbos irregulares. Ao mesmo tempo, aparece a gramática do latim e do francês. No segundo ano, são arrolados os conteúdos de ensino do francês, latim e inglês; no terceiro, aparece o alemão e o latim; no quarto e quinto ano, francês, inglês, alemão, latim e grego; no sexto, além dessas línguas, aparece o ensino de retórica, contemplando alguns aspectos de construção de frase e período, estilo, figuras de linguagem e de construção; no sétimo ano, a mesma configuração do sexto é mantida, sendo que a retórica centra-se nas características da poesia e nos estudos da poesia grega, lusitana e de apenas uma obra brasileira - "Caramuru”, de José Santa Rita Durão (VECHIA; LORENZ, 1998, p. 26). É notória a primazia das línguas clássicas e estrangeiras em detrimento da língua vernácula neste período.

Segundo Vechia e Lorenz (1998, p. 28), no programa de ensino do Colégio Pedro II para o ano letivo de 1856, o ensino da língua vernácula também aparece apenas no primeiro ano, como base para o ensino de latim e das demais línguas, no entanto não há prescrição de assuntos específicos, apenas há a sugestão de uso da "Grammatica da lingua portugueza” de Cyrillo Dilermando. Continuam sendo prescritas as línguas latim, grego, francês, alemão, inglês através de sugestões de livros a serem adotados. A retórica aparece novamente no sexto ano e versa sobre os principais escritores, oradores e poetas antigos e modernos, especialmente gregos, latinos e lusitanos. Somente no sétimo ano é que a literatura brasileira é contemplada na disciplina de Retórica por meio da preparação para fruir as belezas dos textos literários dos grandes autores, além disso, os alunos são levados a compor textos literários e a escrever elegantemente, imitando os modelos indicados pelo professor. 
No ensino prescrito para o ano de 1858, a língua vernácula continua apenas no primeiro ano, abordando os estudos de gramática, leitura, recitação e exercícios ortográficos (VECHIA; LORENZ, 1998). A primazia das línguas clássicas e estrangeiras continua em voga. A retórica aparece novamente no sexto ano, abordando as melhores passagens dos autores antigos, lusitanos e brasileiros. É nesse momento que aparece, pela primeira vez, a crítica literária. No sétimo ano há uma novidade: a disciplina passa a ser denominada de Retórica e Poética, em que são contemplados exercícios de composição, em prosa e verso, discursos, narrações declamações e, finalmente, há o aparecimento da história da literatura portuguesa e nacional.

As novidades do programa de ensino de 1862 são o aparecimento da disciplina de Gramática Filosófica e Retórica no sexto ano e as novas disciplinas de Literatura e Poética. Os assuntos prescritos em Gramática Filosófica arrolam a ortoépia, a ortografia, a etimologia, a sintaxe e a análise lógica da língua portuguesa. No sétimo ano, cria-se a disciplina Literatura Nacional, em que a literatura é dividida em escolas literárias, desde o trovadorismo até a escola romântica, e a poética que aborda os gêneros literários. $\mathrm{O}$ latim ainda continua prescrito em todos os anos; continuam em voga as línguas inglês, francês, alemão e grego.

Como mostra Razzini (2000), em 1869, através do Decreto 4.430, o português passou a fazer parte dos exames preparatórios, ao mesmo tempo em que diminuía o número de aulas consagradas ao latim. Segundo Piletti (1987), o português passou a ser exigido nos exames para ingresso em qualquer curso superior. Tem início, então, a ascensão da disciplina nos planos da educação secundária no Brasil. Segundo Razzini (2000), até 1890, o ensino do português envolvia a gramática (expositiva e histórica), leitura expressiva e recitação de trechos de prosadores e poetas brasileiros e portugueses do século XIX, leitura de autores clássicos como Camões, Vieira, Luiz de Souza, Bernardes, entre outros, exercícios ortográficos e composição, retórica e poética, mais tarde acompanhadas de Literatura Nacional. Intensificaram-se especialmente os exercícios escritos de redação e composição, com ênfase na produção de textos ancorados em práticas adotadas no ensino da retórica e da poética.

A disciplina "português" aparece pela primeira vez no programa de ensino de 1877, no primeiro e segundo anos (VECHIA; LORENZ, 1998, p. 68). O programa abarca tonicidade, morfologia, sintaxe, ortografia e figuras de linguagem da língua vernácula, além de análise lógica e etimológica da língua e recitação de prosadores e poetas clássicos. No quinto ano, a disciplina de Retórica prescreve exercícios de composição em prosa e de 
exercícios orais de eloquência; a disciplina de Poética se atém aos gêneros literários e à poesia em geral. O latim é prescrito apenas para os segundo, terceiro e quarto anos, além dele, há também a diminuição das cadeiras referentes às outras línguas. Em 1878, a disciplina "português" é ministrada apenas no sétimo ano, através da gramática, análise da língua e exercícios de redação verbal e escrita (VECHIA; LORENZ, 1998, p. 68). O latim é recomendado somente para os primeiros três anos; há a inserção da língua italiana, além de algumas cadeiras das demais línguas modernas já prescritas anteriormente essas mudanças são bastante significativas para o fortalecimento da língua nacional.

É nessa época que se começou a problematizar a respeito do português falado no Brasil. Segundo Felisbino (2013), houve manifestações de ordem ideológica acerca da busca da identidade nacional e da emancipação da língua. Silva, em seu Systema de orthografia brasileira (1880), defendeu uma suposta língua brasileira por meio da comparação entre as pronúncias do português brasileiro e do português europeu, ressaltando a introdução das palavras indígenas na nossa língua e de vocábulos que só aqui existiam.

Em 1882, é prevista, pela primeira vez, a divisão do programa de ensino de português para o primeiro ano em leitura e recitação, exercícios ortográficos, gramática e composição. É nesse momento que o ensino da língua vernácula também é prescrito para o segundo, terceiro, quarto e para o quinto ano. O latim fica prescrito do segundo ao quinto ano. Para os últimos anos, permanecem previstas as disciplinas de Retórica, Poética e Literatura Nacional (VECHIA; LORENZ, 1998). Esse quadro se mantém até o programa de 1898.

Até o fim do Império, o ensino da língua vernácula no ensino secundário se fazia nesses termos. $\mathrm{O}$ sistema de exames parcelados como condição de ingresso no curso superior foi modificado pelo Decreto n. 9.647 de 2 de outubro de 1886 que estabelecia a aprovação em Português como condição para realizar as provas das demais disciplinas (PILETTI, 1987). Além disso, as reformas e programas posteriores acabaram por extinguir também as disciplinas de Retórica e Poética (mas não de Gramática) e por criar a disciplina de História da Literatura incorporando como conteúdos, práticas de leitura - recitação e composição - redação (essa disciplina foi incorporada ao ensino da língua vernácula em 1911 (RAZZINI, 2000)). Para isso, eram utilizados textos de autores consagrados, cabendo ao professor - e somente a ele - "comentá-lo[s], discuti-lo[s], analisá-lo[s] e propor questões e exercícios aos alunos" (SOARES, 2004, p. 166). Houve, na verdade, uma fusão desses saberes em uma só denominação, o que não significou uma mudança de conteúdos e objetivos, conforme ressalta Razzini (2000, p. 75): 
A carga horária do curso secundário reforça a já assinalada ascendência do português e o declínio da retórica e poética, até sua extinção em 1890. Entretanto, a análise dos Programas do Colégio Pedro II revela a lenta transferência e adaptação de velhas técnicas retóricas e poéticas para o currículo de português, ao invés de registrar seu simples desaparecimento. É, pelo menos nesse sentido, que se pode interpretar a introdução, no currículo de português, de leitura e recitação (1855), autores clássicos nacionais, portugueses e brasileiros (1860), redação e composição (1870).

Assim, a retórica e a poética assumiram o caráter de estudos estilísticos; o falar bem foi substituído pelo escrever bem, que era a exigência da época; persistiu a aprendizagem sobre o sistema da língua e a análise de textos consagrados.

Essa tradição no ensino da língua vernácula, segundo Soares (2004), servia aos propósitos do ensino secundário: a educação de um grupo economicamente privilegiado, único a ter acesso à escola, e a quem continuavam a ser úteis essas mesmas aprendizagens. Para Razzini (2000), o poder da classe dominante era legitimado pelo acesso restrito à cultura europeia - principalmente ao modelo francês - e supervalorizava a elite letrada, digna representante do país frente às nações mais adiantadas, embora a infraestrutura educacional para a educação dos altos escalões fosse insignificante, se comparada aos padrões europeus. Essa era a conjuntura: o ensino a serviço da hegemonia da classe dominante.

Conforme Razzini (2000), houve uma aproximação da prática de ensino dos clássicos com a prática de ensino dos clássicos nacionais. Essa aproximação se deu através da constituição de uma história literária nacional e de um rol das obras consideradas clássicos nacionais. Assim, também a técnica de ensino da gramática nacional remontava a da gramática latina: exemplificando as estruturas gramaticais através de trechos de autores clássicos, a exemplo do ensino gramatical e retórico dos vernáculos europeus. Assim, a literatura brasileira "ganhou espessura e autoafirmação, servindo cada vez mais de exemplo nas aulas de português" (RAZZINI, 2000, p. 50). Essas práticas de ensino do vernáculo foram importantes para a implantação de uma cultura nacional, processo em marcha a partir da independência do Brasil.

Com a proclamação da República, o ensino da língua vernácula prestava-se à construção da nacionalidade brasileira, constituindo-se um instrumento de integração e unidade nacional. Saber ler e escrever era imprescindível para formar esse novo cidadão, uma vez que era o meio para assimilação da moral, a base para aprendizagem de novos conhe- 
cimentos e para o exercício da cidadania, lembrando que para exercer o direito do voto, nesse período, era necessário saber ler e escrever.

Os republicanos, nutridos pelos ideais liberais e pelos novos modelos de educação que surgiam nos países civilizados, deram maior importância à educação primária - foram criados os grupos escolares e as reformas que modernizaram a pedagogia primária, ampliando o acesso à escola, contudo o ensino secundário regular nesse período continuava sendo oferecido apenas pela iniciativa privada e através dos estudos parcelados, ainda privilegiando as elites do país (SOUZA, 2010). Conforme Souza (2008), a formação do cidadão republicano ancorou-se no cultivo da formação cívico-patriótica pela afirmação da nação como projeto político, mas as mudanças educacionais implementadas no início da República ratificavam a distinção entre educação do povo e educação da elite, principalmente no ensino secundário, uma vez que a elite era preparada para o ingresso nos cursos superiores, uma aspiração que estava longe para os jovens das classes menos favorecidas. Dessa forma, segundo Souza (2008), visando à manutenção de uma alta cultura, os herdeiros da elite recebiam uma formação em latim, língua portuguesa, línguas modernas, literatura, história, geografia e filosofia, aritmética, álgebra, geometria, trigonometria, mecânica, astronomia, física, química e história natural, porém as ciências eram tidas como complementares à formação beletrista.

A importância do ensino da língua vernácula, que já vinha se intensificando, aumentou com o nacionalismo marcante dessa época e com os vínculos estabelecidos pela intelectualidade brasileira entre a língua pátria e a identidade nacional. Segundo Souza (2008), o estudo da gramática não foi abandonado, enquanto que se intensificaram os exercícios de redação e composição, ancorados no ensino da retórica e da poética. O estudo da literatura viria reforçar o conteúdo nacional da cultura geral, ministrada no ensino secundário. De acordo com Souza (2008), num primeiro momento a história da literatura brasileira destacava suas raízes lusitanas; as lições seguintes abordavam a literatura brasileira no período colonial, os cronistas, oradores e poetas do século XVII, a poesia épica, lírica, religiosa e patriótica da escola mineira; e, finalmente, os poetas, os críticos, os jornalistas e o movimento científico e artístico do período romântico. Quanto às línguas clássicas, conforme Souza (2008), a reforma do ministro Maximiliano, em 1915, eliminou a obrigatoriedade do ensino do grego no secundário, mantendo o latim em posição de igualdade com as demais línguas - português, francês, inglês e alemão.

No programa de Português de 1926, para o ensino secundário do Colégio Pedro II, vê-se, claramente, a prescrição do ensino da língua carregada do nacionalismo, influencia- 
do principalmente pelo surto nacionalista devido à Primeira Guerra Mundial. Para o primeiro ano, é recomendado que se reflita sobre a língua portuguesa e suas parentas, em pé de igualdade com as demais línguas, além de refletir acerca da evolução da língua. Como indicação de livros, destacam-se "Analyse Grammatical e lógica. O idioma nacional” de Antenor Nascentes e "O meu idioma" de Othoniel Motta (VECHIA; LORENZ, 1998, p. 245). Contudo, o ensino da língua vernácula é prescrito apenas para os três primeiros anos, enquanto o latim permanece nos segundo, terceiro e quarto anos.

Assim como no currículo de Português, a língua vernácula ganhava cada vez mais importância para a implantação da cultura nacional e estava cada vez mais sujeita à intervenção do Estado. A ortografia da língua vernácula, no começo do século XX, passou a ser problematizada. Segundo Felisbino (2013), até então as palavras eram grafadas de acordo com sua origem etimológica, conservando a grafia mesmo que não tivesse valor fonético nenhum - chamada de pseudoetimológica, o que levou a uma distância muito grande entre a fala e a escrita. A grafia fora se transformando e até mesmo palavras que não provinham do latim ganharam aspectos dos vocábulos latinos, apresentando complicações e equívocos de toda ordem. Em 1904 foi publicada a Ortografia Nacional, do foneticista português Gonçalves Viana (apud FELISBINO, 2013, p. 75), em que era proposto um sistema simplificado aceitável e exequível, fixando a grafia das palavras com base na sua verdadeira etimologia. Segundo Botelho (2008, p. 165), entre as mudanças estava a supressão de aspectos próprios da etimologia grega - "th, ph, rh"; a simplificação das consoantes gêmeas, mantendo o "rr" e "ss", intervocálicos; a eliminação de consoantes mudas; e a regulamentação quanto ao uso do acento gráfico.

Em 1910, Portugal se tornou República, o que levou a Academia de Ciências de Lisboa a propor uma revisão da ortografia nacional; o país aderiu, então, ao sistema proposto por Viana com poucas modificações. A adoção desta nova ortografia, sem a discussão com o Brasil, causou mal-estar entre as nações irmãs, ficando os dois países com ortografias completamente diferentes, Portugal com a ortografia reformada e o Brasil com a velha ortografia pseudoetimológica.

Segundo Cunha (2009), a proposta para simplificação do foneticista chegou ao Brasil e foi bastante discutida por membros da Academia Brasileira de Letras. Em 1915, foi apresentado o projeto do Filólogo Silva Ramos, que ajustou a ortografia brasileira aos moldes da portuguesa de 1911. O projeto, no entanto, não foi sancionado. Mas, em 15 de junho de 1931, Brasil e Portugal enfim assinam o Decreto no 20.108, o primeiro acordo ortográfico luso-brasileiro sobre o uso da ortografia, com base no sistema simplificado 
proposto por Viana. Segundo Felisbino (2013), a sistematização da ortografia nesse momento teve um caráter não apenas de simplificar e fixar a ortografia, mas também, e sobretudo, nacionalista, fazendo referência às marcas entre a pronúncia brasileira em relação à pronúncia europeia, ampliando e intensificando, dessa forma, a procura da identidade nacional por meio da criação de um sistema gráfico brasileiro. A obra de Viana representou um marco na história da grafia das palavras.

O primeiro acordo ortográfico foi firmado em 30 de abril de 1931 e implantado nas repartições públicas, nas escolas, no Diário Oficial e nas demais publicações oficiais, segundo Razzini (2000). A Academia Brasileira de Letras foi incumbida de preparar o Vocabulário Ortográfico e Ortoépico da Língua Portuguesa, que se tornou vigente no país a partir de sua publicação em 1932. Contudo, segundo Cunha (2009), depois de oficializado, o acordo de 1931 é derrubado pela Constituição brasileira de 1934, que mandava voltar à ortografia da Constituição de 1891. Só em 1938, a paz ortográfica é restabelecida, com a aplicação da ortografia firmada em 1931. Inicia-se, ali, um processo de uniformização da ortografia brasileira e portuguesa, mas os vocabulários que se publicaram a partir daí ainda continham divergências entre as duas grafias. Um novo acordo foi assinado em 1943 e tornado lei em Portugal, mas não foi ratificado pelo governo brasileiro, que manteve a ortografia estipulada pela Academia Brasileira de Letras na publicação da convenção ortográfica anterior ao acordo. Essa grafia se manteve no Brasil até o acordo de 1971.

Esse sentimento nacionalista, junto com a revolução de outubro de 1930, trouxe novas determinações para o ensino no Brasil. O país tentava adequar-se ao projeto da construção da sua nacionalidade, consoante com as novas demandas em virtude dos avanços tecnológicos e do crescimento urbano. A ignorância do povo seria o freio ao progresso do país. Além disso:

Nas décadas de 1930 e 1940, durante o governo de Getúlio Vargas, o nacionalismo brasileiro alimentou-se de um projeto autoritário e centralizador. Na vigência do Estado Novo, a política de nacionalização, empreendida pelo governo federal, buscou erradicar as minorias étnicas, lingüísticas e culturais, atuando sobre os núcleos de colonização estrangeira. [...] Os professores primários foram conclamados para essa campanha nacionalista e boa parte do magistério assumiu tal empreendimento como causa cívica. (SOUZA, 2008, p. 72).

Esse era um terreno profícuo para alicerçar o ensino de uma língua que fosse nacional e que fortalecesse a nação.

Em 1931, a reforma Francisco Campos insere pela primeira vez o ensino de língua 
portuguesa em todos os anos do ensino fundamental (DALLABRIDA, 2009). Além disso, opera grandes transformações no ensino secundário e estabelece uma série de medidas como o aumento do número de anos do curso secundário; a divisão em dois ciclos, a seriação do currículo; a frequência obrigatória; a imposição de um sistema de avaliação discente e a reestruturação do sistema de inspeção federal. $\mathrm{O}$ curso secundário foi dividido em dois ciclos: o primeiro, com duração de 5 anos - o 'fundamental' -, tinha o objetivo de conferir uma formação geral ao educando; o segundo, com duração de dois anos - o 'complementar'-, conferia uma formação voltada ao curso superior almejado pelo aluno. Essa reforma promoveu importantes transformações a caminho da modernização do ensino:

\begin{abstract}
A Reforma Francisco Campos homogeneizou, de forma inédita, a cultura escolar do ensino secundário brasileiro, pois estabeleceu oficialmente procedimentos administrativos e didáticos-pedagógicos para todos os ginásios do território nacional. (DALLABRIDA, 2009, p. 188).
\end{abstract}

Embora não tenha rompido com o passado, as inovações promovidas por essa reforma foram significativas, pois instaurou as bases da organização escolar sobre a qual ocorreria a expansão do ensino nas décadas seguintes.

A reforma de Francisco Campos procurou desvincular o ensino secundário do caráter propedêutico que até então possuía. Segundo Gatti et al. (2014), a finalidade exclusiva apontada para o ensino secundário deveria ser a formação do homem para todos os grandes setores da atividade nacional e não somente a matrícula nos cursos superiores, por isso há um declínio das letras clássicas e uma tonificação das ciências naturais. $\mathrm{O}$ ensino secundário deveria formar hábitos e valores necessários ao desenvolvimento do indivíduo em relação ao Estado.

O ministro também instituiu nacionalmente o exame ${ }^{3}$ que permitia a passagem do ensino primário para o secundário (BASTOS; ERMEL, 2014). O exame era realizado no final da quarta série do ensino primário através de provas escritas eliminatórias, de português e aritmética, e de provas orais de português, aritmética, história do Brasil e geografia. Segundo Bastos e Ermel (2014, p. 120), a prova escrita de português era composta de redação e ditado e visava a aferir as condições reais do candidato ao curso secundário quanto ao seu desembaraço caligráfico. Os exames orais visavam a apurar o grau de desenvolvimento da linguagem expressiva do candidato.

Quanto aos parâmetros para o ensino da língua vernácula, Razzini (2000, p. 99)

\footnotetext{
${ }^{3}$ Esse exame vigorou até a promulgação da Lei 5.692 de 1971, conforme Bastos e Ermel (2014).
} 
descreve o programa para ciclo fundamental dessa época, prescrito pelo Ministério da Educação e Saúde: a) O ponto de partida de todo o ensino seria a leitura dos "bons escritores”, começando com os prosadores e poetas contemporâneos nas duas primeiras séries, passando pelos modernos nas $3^{\mathrm{a}}$ e $4^{\mathrm{a}}$ séries, terminando com os clássicos na $5^{\mathrm{a}}$ série, obedecendo, então, uma ordem cronológica inversa; b) os exercícios de leitura estavam sujeitos a uma ordem que ia da "explicação dos textos" e do "estudo metódico do vocabulário" (da $1^{\mathrm{a}}$ à $3^{\mathrm{a}}$ série) até a «interpretação» dos trechos e a «análise literária» nas últimas séries $\left(4^{\mathrm{a}}\right.$ e $\left.5^{\mathrm{a}}\right)$; c) o ensino da oralidade e da escrita também era gradativa, começando sempre com exercícios orais, os quais, a partir da $3^{\mathrm{a}}$ série, eram seguidos de exercícios escritos, utilizando a descrição, narração e dissertação, nessa ordem; d) o ensino da gramática concentrava-se inicialmente na morfologia e na sintaxe ( $1^{\mathrm{a}}$ à $3^{\mathrm{a}}$ série), acrescentando depois a fonética ( $3^{\mathrm{a}}$ série), a gramática histórica, drasticamente reduzida a alguns tópicos, na quarta série, e a $5^{\mathrm{a}}$ série era reservada para o estudo da literatura (noções, história e análise) e para os exercícios escritos mais depurados («composição e estilo»). Fica evidente, tanto na precedência da leitura quanto na abordagem menos teórica da gramática e na maior atenção com os exercícios orais e escritos, que o ensino de português voltava-se para o ensino prático do vernáculo.

No ensino do português, há uma crescente ênfase à aquisição da língua nacional e ao aprendizado da fala e da escrita corretas. Souza (2008) aponta que, depois de instaurada a disciplina, o ensino da língua vernácula tinha por objetivo proporcionar ao estudante a aquisição efetiva da língua portuguesa, habilitando-o a expressar-se bem, na escrita e na fala, e incitando nele o gosto pela leitura dos bons escritores, dando-lhe o indispensável para a boa formação de seu espírito bem como para a sua educação literária. A ênfase ao ensino da língua vernácula advém do sentimento de nacionalismo emergente desde a Primeira Guerra Mundial com a luta pela construção de uma identidade nacional e consolidada na revolução de 1930 (DALLABRIDA, 2009).

O programa de ensino do ano de 1942 prescrevia, para o curso ginasial, o ensino da língua vernácula pautado em três frentes: a leitura, a gramática e outros exercícios (VECHIA; LORENZ, 1998). No primeiro ano ginasial, a ênfase recaía em textos que versavam sobre a família, a escola e a terra natal; os textos serviam de base para o estudo da morfologia e da sintaxe (não ultrapassando o período composto por coordenação); além de exercícios de ortografia, do estudo do vocabulário e de breves composições orais e escritas. Já no segundo ano, os assuntos recaíam sobre a paisagem e a vida nas diversas regiões do Brasil; novamente aparece a morfologia e a análise sintática, mas evoluía-se 
para as normas de regência e o uso da preposição; novamente, vocabulário, ortografia e composição oral e escrita. Para a terceira série ginasial, os textos eram subordinados à ideia do amor à terra brasileira; análise léxica e sintática dos períodos subordinados, colocação pronominal e estudos do vocabulário. No último ano ginasial, havia a iniciação à literatura brasileira e portuguesa; estudos fonéticos e fonológicos, vocabulário, alguns gêneros textuais e noções do latim e suas declinações. $O$ programa também apresenta as línguas francês e inglês e as ciências naturais. Como é evidente, houve um crescimento acentuado da gramática expositiva (ou normativa) em relação à reforma anterior, conforme é apontado por Razzini (2000), principalmente da morfologia e da sintaxe, nas três séries iniciais do ginasial, enquanto a fonética e algumas noções de gramática histórica foram introduzidas na $4^{\mathrm{a}}$ série.

Já para os cursos clássico e científico, a compilação de Vechia e Lorenz (1998) apresenta, no programa de português para o primeiro ano, noções gerais de literatura - agora já inclusa no ensino de língua vernácula; gramática, pautada na análise sintática; leitura de autores portugueses da primeira escola literária, o trovadorismo; e exercícios de composição oral e escrita de alguns gêneros textuais. No segundo ano, o programa prescreve noções da história da literatura portuguesa das eras medieval, clássica e moderna; gramática, pautada nas normas padronizadas do uso da língua quanto à concordância e regência; leitura de autores portugueses, além de exercícios de composição de biografias de grandes vultos da literatura e análise literária. Para a terceira série, a literatura brasileira é prescrita nas eras colonial e nacional até o movimento modernista; leitura de autores brasileiros e composições orais e escritas; não há ensino de gramática. As línguas modernas continuam prescritas - espanhol, inglês, francês - além do ensino opcional do grego no curso clássico. São notórios o nacionalismo dominante nesse período e as significativas mudanças por que passou a disciplina de português, mas, segundo Razzini (2010), ao lado do critério da nacionalidade persistiam os textos que respeitavam o padrão da língua, havia a mesma preocupação dos períodos anteriores com a vernaculidade e a pureza da língua nos moldes dos escritores clássicos portugueses.

A implementação dessas duas reformas, ambas estabelecidas durante o governo de Vargas (a Reforma Francisco Campos em 1931 e a Reforma Capanema em 1942), foi importante para a constituição da educação secundária no Brasil. Segundo Souza (2008, p. 145), elas:

fixaram a estrutura organizacional e ratificaram o projeto cultural de formação da juventude que consagraria, no país, o modelo de escola 
secundária concebida como educação das elites condutoras da nação, privilegiando a cultura geral desinteressada e de caráter altamente seletivo.

No que diz respeito à disciplina de Português, ambas foram essenciais para a transformação da educação e para a consolidação do ensino da língua vernácula no Brasil.

No programa de 1951, a disciplina de Português para os quatro anos do curso ginasial do ensino secundário brasileiro mantém a taxionomia como elemento principal do ensino da língua vernácula - categorias morfológicas, análise sintática e classificação das orações -, seguida do cuidado com a ortografia e com o vocabulário, além da leitura dos grandes prosadores e poetas brasileiros e portugueses. Para o curso colegial, o programa de 1951, publicado na coletânea de Vechia e Lorenz (1998), traz algumas mudanças: as análises linguísticas recaem sobre noções de fonética e morfologias históricas, formação do vocabulário e comentários gramaticais. A ênfase é dada à leitura, interpretação e análise e história das escolas literárias brasileiras e portuguesas, bem como à composição escrita e exposições orais. As línguas modernas - francês, inglês e espanhol - ainda se fazem presentes, enquanto que o latim volta a ser ministrado em todos os anos do secundário e o grego, nos três primeiros anos do curso clássico.

A partir daí, as mudanças no ensino secundário no Brasil foram influenciadas pelo contexto histórico e econômico dos anos 1950 - era de ouro no Ocidente, marcado pelo crescimento acelerado seguido de diversos aspectos sociais que caracterizaram uma fase excepcional do capitalismo. Da mesma forma, houve o crescimento acelerado de acesso ao ensino secundário no Brasil. Segundo Nascimento (2015), é nesse contexto de desenvolvimento econômico nacional associado ao capital estrangeiro e da crescente urbanização das capitais das federações que nascem as linhas gerais da educação brasileira com a elaboração da Lei de Diretrizes e Bases da Educação Nacional (LDB). ${ }^{4}$ A expansão acelerada do ensino secundário não só fomentou novos rumos na educação brasileira, mas também incentivou mudanças na constituição dos currículos e dos objetivos das disciplinas.

Nessa efervescência, começa a ocorrer uma expressiva modificação no ensino da língua vernácula. Segundo Soares (2004), as transformações das condições sociais e culturais do país, sobretudo no que diz respeito ao acesso à escola, vão exigir uma reformulação da função e dos objetivos da instituição escolar: os alunos já não são apenas os filhos da burguesia; o recrutamento de professores se torna mais amplo e menos seletivo. Essas

\footnotetext{
${ }^{4}$ Conforme Gatti et al. (2014, p. 201), a LDB de 1961 flexibilizava e diversificava o currículo e práticas educativas, e equiparava o ensino secundário e os cursos técnicos e normal através da criação do "ensino médio", superando formalmente o dualismo escolar.
} 
condições escolares e pedagógicas exigem outro tipo de ensino. Como afirma Soares (2004, p. 167), o ensino da gramática passa a ser articulado com o ensino de texto: "ora é na gramática que se vão buscar elementos para a compreensão e a interpretação de texto, ora é no texto que se vão buscar estruturas linguísticas para a aprendizagem da gramática”. Soares (2004) ressalta a primazia que o estudo da gramática teve desde os tempos do sistema jesuítico no ensino secundário brasileiro. Essa força da tradição explicaria a primazia que é dada ainda hoje ao ensino da gramática na escola.

\section{Algumas considerações}

As considerações aqui não querem ser conclusivas, mas instigantes para a volta à questão que norteia os estudos sobre cultura escolar. Nesses estudos estão pressupostas regularidades institucionais, tradições, sedimentação de práticas que sobrevivem às reformas e inovações. Reconhecer essas permanências não permite desconsiderar as transformações por que passa a cultura escolar, bem como todos os processos culturais, mas há de se constatar que as transformações pelas quais passou a disciplina de português no Brasil pouco mudaram a concepção predominante na seleção cultural desse ramo de ensino: a de dar primazia à análise gramatical - especialmente morfológica e sintática - e de pautar sua prática na cultura da elite e nos estudos literários.

Na linha evolutiva da constituição da disciplina Português no Brasil observam-se transformações que vão dando contornos aos discursos e proposições pedagógicas que, por sua vez, acompanham mudanças de conteúdos e métodos, articuladas às mudanças culturais da sociedade. Assim, à época dos jesuítas o culto das humanidades se fez perceber mesmo depois do fechamento das escolas da Companhia de Jesus, o que continuou a ser a ênfase no Colégio Imperial Dom Pedro II. A disciplina de Português, que começou sob a denominação de Retórica e Poética, teve início somente em 1871, juntamente com a profissão de professor de português, exercida por estudiosos da língua que deram ao ensino um caráter essencialmente propedêutico. Os estudos linguísticos, insipientes na época, não abarcavam as muitas variedades de linguagem, forjando um ensino de língua pautado numa variante única e elitizada, além de seguir a tradição do ensino do latim, em que os estudos se baseavam na análise gramatical da língua. $\mathrm{O}$ currículo do português também esteve sob o jugo dos exames preparatórios para o ingresso nos cursos superiores, fato que moldou o ensino para as habilidades exigidas dos bacharéis em letras, os quais cultivavam grande distinção social pela arte do bem falar e escrever. Além disso, é notória a primazia dada ao ensino das línguas clássicas em detrimento da língua vernácu- 
la, fato que só se modificou a partir da reforma Francisco Campos e que, apesar da volta às humanidades prescrita por Capanema, teve gradativa ascensão graças à necessidade de constituição da nação brasileira, impulsionando o ensino da língua vernácula para um patamar superior ao que ocupava. Esse ensino gramatical e o caráter elitista do ensino secundário estão presentes nas escolhas curriculares e nos métodos até os dias de hoje. Vêse que, na sua evolução, as prescrições acerca do ensino da língua vernácula vão revelando concepções de mundo e pedagógicas que se sedimentaram nas práticas dos professores, apesar das mudanças e das inovações.

É certo que os estudos sobre cultura escolar abarcam tanto o prescrito quanto o praticado. No entanto, nosso intuito neste texto é dar subsídios aos pesquisadores que trabalham com a história da disciplina de português acerca das mudanças na legislação e nas propostas curriculares desse segmento, pois para desnaturalizar objetos e práticas é preciso conhecê-los a fundo. A partir daí é preciso empreender um esforço investigativo para desvendar o universo intramuros da escola e verificar, quando as fontes nos permitem, o que foi feito com as prescrições. Reconhecemos, então, a importância e necessidade de maiores investimentos em estudos que visem à caracterização da cultura escolar efetivamente praticada a partir das prescrições aqui elencadas.

\section{Referências}

ALMEIDA, R. A. O diretório dos índios: um projeto de "civilização" no Brasil do século XVIII. Brasília: Editora UnB, 1997. Disponível em: http://www.nacaomestica.org/diretorio dos_indios.htm. Acesso em: 24 abr. 2015.

AZANHA, J. M. P. Cultura escolar brasileira: Um programa de pesquisas. Revista USP, $\mathrm{n}$. 8, p. 65-69, dez./fev., 1990.

BASTOS, M. H. C.; ERMEL, T. F. Ritos de passagem, classificação e mérito: os exames de admissão ao ginásio (1930-1961). In: DALLABRIDA, N.; SOUZA, R. F. Entre o ginásio de elite e o colégio popular: estudos sobre o ensino secundário no Brasil (1931-1961). Uberlândia, EDUFU, 2014.

BITTENCOURT, C. M. F. Disciplinas escolares: História e pesquisa. In: TABORDA DE OLIVEIRA, M. A.; RANZI, S. M. F. História das disciplinas escolares no Brasil: Contribuições para o debate. Bragança Paulista, EDUSF, 2003.

BOTELHO, J. M. Um pouco de história da ortografia da língua portuguesa. SOLETRAS (UERJ), v. único, p. 157-171, 2008.

BRASIL. Governo Provisório da República dos Estados Unidos do Brasil. Decreto no 19.890, de 18 de abril de 1931. Rio de Janeiro, 18 de abril de 1931. Disponível em: http://www2.camara.leg.br/legin/fed/decret/1930-1939/decreto-19890-18-abril- 
1931-504631-publicacaooriginal-141245-pe.html. Acesso: 24 abr. 2015.

CARVALHO, M. C. A Escola e a República e outros ensaios. Bragança Paulista: EDUSF, 2003.

CHERVEL, A. História das disciplinas escolares: reflexões sobre um campo de pesquisa. Teoria ఓ Educação, Porto Alegre, n. 2, p. 177-229, 1990.

CUNHA, R. Embates e acordos na história das reformas ortográficas. Revista Ciência e Cultura, v. 61, n. 2, 2009.Disponível em: http://cienciaecultura.bvs.br/scielo.php?script=sci_ arttext\&pid=S0009-67252009000200003. Acesso em 24 abr. 2015.

DALLABRIDA, N. A reforma Francisco Campos e a modernização nacionalizada do ensino secundário. Revista Educação. Porto Alegre, v. 32, n. 2, p. 185-191, maio-ago. 2009.

FARACO, C. A. Norma-padrão brasileira: desembaraçando alguns nós. In: BAGNO, M. (Org.). Linguística da norma. São Paulo: Loyola, 2004.

FELISBINO, A. M. O percurso histórico da ortografia da língua portuguesa. Revista Inovação Tecnológica, São Paulo, v.3, n. 1, p. 67-79, jan./jun. 2013.

GATTI, G. C. V. et al. Reformas e expansão do ensino secundário no Brasil: o caso do Colégio Estadual de Uberlândia, em Minas Gerais (décadas de 1930 a 1960). In: DALLABRIDA, N.; SOUZA, R. F. Entre o ginásio de elite e o colégio popular: estudos sobre o ensino secundário no Brasil (1931-1961). Uberlândia, EDUFU, 2014.

GONÇALVES, I. Cultura escolar: Práticas e produção dos grupos escolares em Minas Gerais (1891-1918). Belo Horizonte. Autêntica, 2006.

JULIA, D. A cultura escolar como objeto histórico. Revista Brasileira de História da Educação, Campinas, n. 1, jan./jun. 2001.

NASCIMENTO, M. N. M. Educação e nacional-desenvolvimentismo no Brasil. Disponível em: http://www.histedbr.fe.unicamp.br. Acesso em: 17 abr. 2015.

PILETTI, N. A evolução do currículo do curso secundário no Brasil. Revista Faculdade de Educação. n. 13. p. 27-72, São Paulo, jul./dez. 1987.

SOARES, M. Português na escola: História de uma disciplina curricular. In: BAGNO, M. (Org.). Linguística da norma. São Paulo: Loyola, 2004.

SILVA, J. J. P. Systema de orthografia brasileira. Rio de Janeiro: Tipografia de Lourenço Winter, 1880.

SOUZA, R. F. História da organização do trabalho escolar e do currículo no século XX: ensino primário e secundário no Brasil. São Paulo: Cortez, 2008.

. A história do ensino secundário no Brasil investigada na perspectiva da cultura escolar. In: CASTRO, C. A. (Org.). Leitura, impressos e cultura escolar. São Luís: EDUFMA. p. 39-66, 2010.

RAZZINI, M. P. G. O espelho da nação: a antologia nacional e o ensino de português e de literatura (1838-1971). Tese de doutorado. Instituto de Estudos da Linguagem. São 
Paulo, UNICAMP, 2000.

ROOTHAN, J. Ratio atque institutio studiorum Societatis Jesu. Paris: Firmon Didot Frates, 1850. Disponível em: https://archive.org/details/ratioatqueinstit00pari. Acesso em: 17 abr. 2015.

VECHIA, A.; LORENZ, K. M. Programa de ensino da Escola Secundária Brasileira (18501951). Curitiba: Ed. do Autor, 1998.

VINÃO FRAGO, A. Historia de La educación e historia cultural: posibilidades, problemas, cuestiones. Revista Brasileira da Educação, São Paulo, n. 0, p. 63-82, 1995. 